\title{
超音波溶湯摚拌法によるアルミニウム合金 溶湯中での安定酸化物の生成複合化
}

\author{
弦間喜和 ${ }^{\dagger}$ 鈴木秀和 ${ }^{\dagger}$ 恒川好樹 \\ 奥宮正洋毛利尚武
}

豊田工業大学工学部機械システム工学科

J. Japan Inst. Metals, Vol. 62, No. 6 (1998), pp. 570-576

\section{In-Situ Formation of Stable Oxides in Molten Aluminum Alloy by Ultrasonic Stirring}

\author{
Yoshikazu Genma ${ }^{\dagger}$, Hidekazu Suzuki ${ }^{\dagger}$, Yoshiki Tsunekawa, \\ Masahiro Okumiya and Naotake Mohri
}

Department of Mechanical Systems Engineering, Faculty of Engineering, Toyota Technological Institute, Nagoya 468-8511

\begin{abstract}
This study is aimed at examining the influence of ultrasonic vibration on the in-situ formation of stable oxides, $\mathrm{Al}_{2} \mathrm{O}_{3}$ and $\mathrm{MgAl}_{2} \mathrm{O}_{4}$, from $\mathrm{SiO}_{2}$ particles added as an oxygen source in melt stirring. The preheated $\mathrm{SiO}_{2}$ particles were added on a molten $\mathrm{Al}$ or $\mathrm{Al}-\mathrm{Mg}$ alloy surface and stirred at $1073 \mathrm{~K}$ in an $\mathrm{Ar}$ atmosphere. The ultrasonic vibration was then transmitted to molten metal through a ceramic plate. The $\mathrm{SiO}_{2}$ particles are not transferred into the molten $\mathrm{Al}$ by melt stirring without ultrasonic vibration. With ultrasonic vibration, the $\mathrm{SiO}_{2}$ particles, which have been transferred into the molten $\mathrm{Al}$ due to the improved wettability, change to stable $\mathrm{Al}_{2} \mathrm{O}_{3}$. The transferred $\mathrm{SiO}_{2}$ particles into the molten $\mathrm{Al}-\mathrm{Mg}$ alloy change to $\mathrm{MgAl}_{2} \mathrm{O}_{4}$ and $\mathrm{Al}_{2} \mathrm{O}_{3}$. The application of ultrasonic vibration to melt stirring makes not only the wettability improve, but also the cracks in the particles grow, which arise from the volumetric shrinkage accompanied with the change from $\mathrm{SiO}_{2}$ to $\mathrm{MgAl}_{2} \mathrm{O}_{4}$ and $\mathrm{Al}_{2} \mathrm{O}_{3}$. The stable oxides are rapidly formed due to the fast diffusion of $\mathrm{Al}$ and $\mathrm{Mg}$ through the cracks. The exothermic reactions of $\mathrm{MgAl}_{2} \mathrm{O}_{4}$ and $\mathrm{Al}_{2} \mathrm{O}_{3}$ formation lead to a temperature rise in the molten $\mathrm{Al}-\mathrm{Mg}$ alloy, in which the temperature rise of $99 \mathrm{~K}$ is approved by applying the ultrasonic vibration. Consequently, the in-situ reactions are promoted further. Gas defects disappear in the solidified $\mathrm{Al}$ alloy containing the stable oxides stirred with ultrasonic vibration, in which the particle distribution is also improved.
\end{abstract}

(Received October 22, 1997; In Final Form February 5, 1998)

Keywords: metal matrix composite, silica particle, molten aluminum-magnesium alloy, ultrasonic vibration, in-situ reaction, melt stirring, stable oxide, gas defect, exothermic reaction

\section{I. 緒言}

金属基複合材料 (MMC)の製造方法として代表的な鋳造法 は，生産性に優れているため，実用化されている MMC 部 品の多くは，この方法によって製造されている。複合化プロ セスとしての鋳造法は，溶浸，溶湯擋拌和よび生成複合化に 分類することができる。しかしながら，溶漫では，セラミッ ク強化材とアルミニウム $(\mathrm{A} 1)$ 溶湯との濡れ性が悪いため, 複合化の際, 一般に $50 \mathrm{MPa}$ 以上の高王を負荷する必要が ある. その対策として，成形体火混合した溶浸助剂と溶湯之 の発熱反応に上る溶湯温度の上昇(1)(2)，成形体に含まれる気 体から固体化合物を生成させ，成形体内を減王して溶湯を吸

†豊田工䇑大学大学院生 (Graduate Student, Toyota Technological Institute)
引する(1)など，新しい着想に基づく無加圧溶浸が報告されて いる、また，マグネシウム $(\mathrm{Mg})$ や珪素 $(\mathrm{Si})$, 窒素 $\left(\mathrm{N}_{2}\right)$ によ る溶浸促進効果を利用した方法が古くから有名である(3).

溶湯擋汼による複合化も数多く報告されている，中でも， 半凝固状態の合金マトリックス以強化材を添加し，複合化す るコンボキャスティングが効果的である。この方法では，溶 湯に含まれる固相之の衝勞作用によって，強化材はマトリッ クスに取込まれ易くなり，七ラミック粒子(4), 短瀻維(5), ウ ネスカー ${ }^{(5)(6)}$ などの複合化例が報告されている。

生成複合化としては，A1 合金溶湯を成形体に溶浸させて 酸素 $\left(\mathrm{O}_{2}\right)$ との反応により $\mathrm{Al}_{2} \mathrm{O}_{3}$ を生成するプロセスがあ る(7). \&た， $\mathrm{A} 1$ 合金溶湯を大気中の $\mathrm{O}_{2}$ によって直接酸化与 る生成複合化る報告されている(8)。この外， $\mathrm{Al}$ ， チタン (Ti)，黑鉛(C)粉末を混合した成形体を，A1溶湯中に浸漬 することにより，微細な TiC を生成する方法 ${ }^{(9)}$, O 供給源 
である $\mathrm{SiO}_{2}$ 粒子の成形体に $\mathrm{Al}$ を溶浸し，その還元によっ $\tau \mathrm{Al}_{2} \mathrm{O}_{3}$ を生成する方法(10)，Al-Ti 合金溶湯へ $\mathrm{CH}_{4}$ を吹込 むことにより，TiC を生成する方法(11)などが報告されてい る。さらに，溶湯擋找を用いた生成複合化プロセスも研究さ れている，例えば，AI-Ti 合金溶湯へC 粒子を添加すること に上って TiC 生成する方法(12), $\mathrm{Al}$ 合金溶湯に $\mathrm{TiO}_{2}$, $\mathrm{KBF}_{4}, \mathrm{Na}_{3} \mathrm{AlF}_{6}$ を添加して，TiBを生成する方法(13)などが 報告されている。

著者らは，超音波振動を溶浸に適用して見挂けの濡れ性を 改善し，低圧あるいは無加压溶浸でも，欠陷を含まない MMC が製造できることを報告した(14)(15)．また，溶湯擋拌 に超音波振動を適用することにより，複合化時間を短縮で き，ガス欠陷の発生を抑制できることを報告した(16)(17)。

本研究では，O供給源として酸化物粒子を用いる生成複 合化に注目する。酸化物粒子は A1 溶湯との濡れ性が悪いた

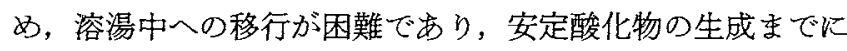
長時間を要する．そこで，酸化物粒子を用いる生成複合化プ ロセスに超音波振動を適用し，溶湯への粒子移行扎よび安定 酸化物生成に対する超音波振動の効果を明らかにする。さら に，O供給源として用いる $\mathrm{SiO}_{2}$ と $\mathrm{Al}$ 溶湯は，発熱を伴う テルミット反応を生じる. 発熱反応によって溶湯温度が上昇 乙, $\mathrm{SiO}_{2}$ 粒子の $\mathrm{Al}$ 溶湯への移行, 寸なわち, 生成複合化を 促進する効果が期待できる。

\section{II. 実験方法}

$\mathrm{SiO}_{2}$ と $\mathrm{Al}$ が反応して $\mathrm{Al}_{2} \mathrm{O}_{3}$ を生成するテルミット反応を 想定し，示差熱分析(DTA)を行った。平均等価直径 $\left(d_{\mathrm{e}}\right)$ が $38 \mu \mathrm{m} \sigma \mathrm{SiO}_{2}$ 粒子と，平均 $d_{\mathrm{e}}$ が $54 \mu \mathrm{m} の \mathrm{~A} 1$ 粉末 $(99.8$ mass\%)をモル比で $3: 4$ に混合した試料を，アルゴン(Ar) 雾团気中で $0.17 \mathrm{~K} / \mathrm{s}$ で昇温し，発熱反応物よび反応開始温 度を調べた。

溶湯表面に添加した $\mathrm{SiO}_{2}$ 粒子を溶湯中に移行させるこ とによ，純 $\mathrm{Al}$ 溶湯中に $\mathrm{Al}_{2} \mathrm{O}_{3}, \mathrm{Al}-\mathrm{Mg}$ 合金溶湯中に $\mathrm{MgAl}_{2} \mathrm{O}_{4}$ や $\mathrm{Al}_{2} \mathrm{O}_{3}$ などの安定酸化物を生成複合化すること を目的として，Fig.1 亿示超音波振動系を備光た溶湯擋 拌装置を自作した。容器内を真空脱気した後, 99.999 vol\% の高純度 $\mathrm{Ar} て ゙$ 置換した雲囲気中で生成複合化実験を行っ た，超音波振動板は，ホーンによって増幅された振動を溶湯 に伝播する役割を果たす、振動板の振動モードの共振周波数 $(P)$ は式(1)で表される(17).

$$
P=\lambda^{2}(E I / \rho A)^{1 / 2}\left(2 \pi l^{2}\right)^{-1}
$$

ここで, $\lambda$ は振動数係数，Eはヤング率，Iは断面二次モ一 メント， $\rho$ は密度， $A$ は振動板の断面積， $l$ は振動板の長さ である、振動板の材質は，著しい溶損のないマシナブルセラ ミックス(BN・AIN 複合体)であり，超音波振動板を溶湯に 浸漬しない時，その形状は共振状態で先端部の振幅が最大 (実測値: 約 $25 \mu \mathrm{m}$ ) となるよ $10 \mathrm{~mm} \times 3 \mathrm{~mm} \times 274 \mathrm{~mm}$ とした(17).ただし，本振動系は11
次振動モード(共振周波数 : $20.26 \mathrm{kHz}$ )であった。溶湯の擋 䢁には，Fig. 1 の左枠内に示したSUS430 製の擋找子を用 いた。撹汼子の溶損を防ぐため，ブラズマ溶射により， $\mathrm{ZrO}_{2}-20$ mass $\% \mathrm{CeO}_{2}$ 層を約 $200 \mu \mathrm{m}$ 被覆した，溶湯量は室 温に特ける体積が $40 \mathrm{~cm}^{3}$ となるよう火し，純 $\mathrm{Al}(99.997$ mass\%)，および Al-9.8Mg-0.02Cu-0.18Fe-0.01Ti(mass\%) 母合金を純 $\mathrm{Al}$ で希秎した $\mathrm{Al}-3$ mass\% $\mathrm{Mg}$ を用いた。 $\mathrm{SiO}_{2}$ 粒子を添加する直前の溶湯温度は $1073 \mathrm{~K}$ とした。

直径 $5 \mathrm{~mm}$ の $\mathrm{SiO}_{2}$ 棒を，Fig. 1 亿示帛超音波振動板から $2 \mathrm{~mm}$ 離して平行に置き，純 $\mathrm{Al}$ 溶湯または $\mathrm{Al}-3$ mass $\% \mathrm{Mg}$ 合金溶湯に $1.8 \mathrm{ks}$ 浸漬した後に引上济た。溶湯中に $\mathrm{SiO}_{2}$ 棒 を浸漬した時に生じる反応層をEPMA 等を用いて調査し， 溶湯中の $\mathrm{Mg}$ や超音波加振の影響を検討した。

次に, Fig. 2 に示导平均 $d_{\mathrm{e}}$ かi $86 \mu \mathrm{m} の \mathrm{SiO}_{2}$ 粒子を $\mathrm{O} の$ 供給源として供試し，純 $\mathrm{Al}$ 溶湯中に打仔る $\mathrm{Al}_{2} \mathrm{O}_{3}, \mathrm{Al}-\mathrm{Mg}$ 合金溶湯中K打忷る $\mathrm{MgAl}_{2} \mathrm{O}_{4}$ や $\mathrm{Al}_{2} \mathrm{O}_{3}$ の生成複合化実験を 行った. $1073 \mathrm{~K}$ に予熱した $20 \mathrm{vol} \%$ の $\mathrm{SiO}_{2}$ 粒子を溶湯表面 に添加し，回転速度 $16.7 \mathrm{~s}^{-1}$ で擋拌した。超音波加振しな がら擋找した時の溶湯温度の変化を測定するとともに， $\mathrm{Al}_{2} \mathrm{O}_{3}$ や $\mathrm{MgAl}_{2} \mathrm{O}_{4}$ の生成量执よび分散状態を観察した。

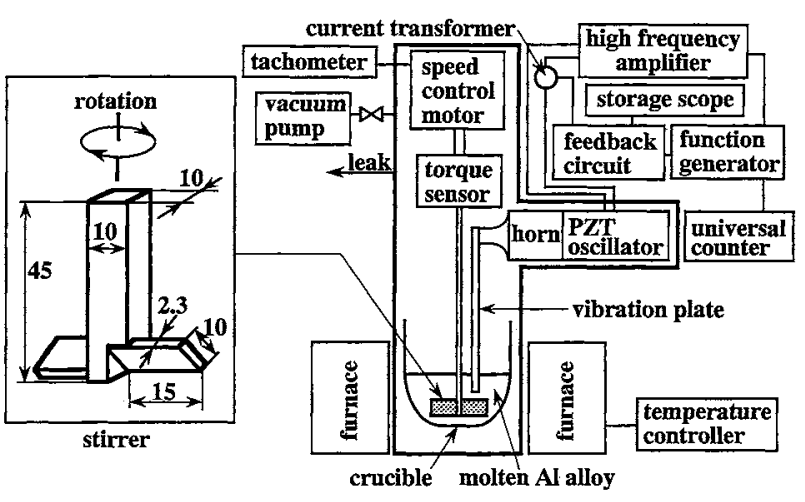

Fig. 1 Schematic diagram of the melt stirring system with ultrasonic vibration.

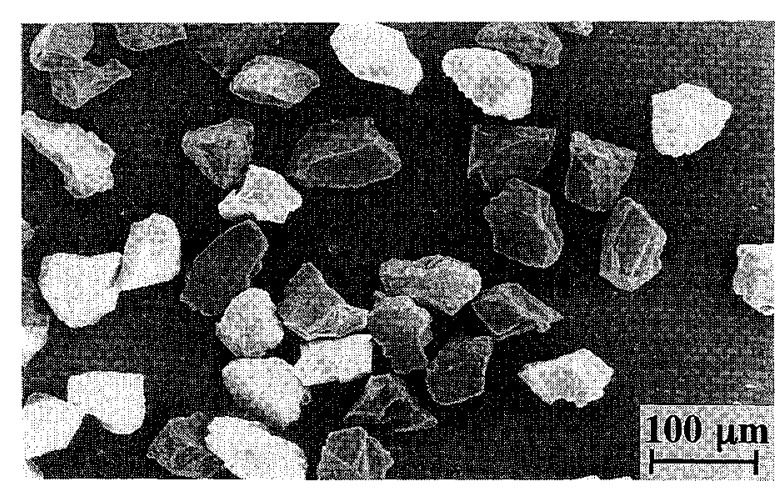

Fig. 2 Scanning electron micrograph of $\mathrm{SiO}_{2}$ particles with an equivalent diameter of $86 \mu \mathrm{m}$. 


\section{III. 実験結果および考察}

\section{1. テルミット反応による発熱}

$\mathrm{SiO}_{2}$ 粒子之 $\mathrm{Al}$ 粉末の混合試料に㧈いて求められた DTA 曲線を Fig. 3 亿示す。温度上昇とともに三ヶ所でピークが 認められる.X線回折結果から, 最初の吸熱ピークは $\alpha$ $\mathrm{SiO}_{2}$ から $\beta-\mathrm{SiO}_{2}$ への変態であり, $930 \mathrm{~K}$ 付近の吸熱ビーク は $\mathrm{Al}$ の溶融飞対応する。そして, $1070 \mathrm{~K}$ 付近の発熱ピー クは式 (2)のテルミット区応である.

$$
\begin{aligned}
& \mathrm{SiO}_{2}+4 / 3 \cdot \mathrm{Al} \longrightarrow 2 / 3 \cdot \mathrm{Al}_{2} \mathrm{O}_{3}+\mathrm{Si} \\
& \Delta H=-225.9 \mathrm{~kJ} / \mathrm{mol}(1073 \mathrm{~K})^{(19)}
\end{aligned}
$$

また， $\mathrm{SiO}_{2}$ 粒子と $\mathrm{Al}-\mathrm{Mg}$ 合金溶湯では，式 (2)に加光て次 の反応も生じる.

$$
\begin{gathered}
\mathrm{SiO}_{2}+\mathrm{Al}+1 / 2 \cdot \mathrm{Mg} \rightarrow 1 / 2 \cdot \mathrm{MgAl}_{2} \mathrm{O}_{4}+\mathrm{Si} \\
\Delta H=-259.9 \mathrm{~kJ} / \mathrm{mol}(1073 \mathrm{~K})^{(19)}
\end{gathered}
$$

ここで， $\Delta H$ は反応時のェンタルピー変化である.

$\mathrm{SiO}_{2}$ 粒子を溶湯表面汇添加する時, 安定酸化物の生成複 合化が瞬時住生じる断熱系を仮定して, 式(2) と式(3)か ら求めた溶湯温度の上昇は, 純 $\mathrm{Al}$ 溶湯で $635 \mathrm{~K}, \mathrm{Al}-\mathrm{Mg}$ 合 金溶湯で $684 \mathrm{~K}$ となる。この発熱によって溶湯温度が上昇 するため, $\mathrm{SiO}_{2}$ 粒子の溶湯中への速やかな移行を生成複合 化速度の上昇が期待できる.

\section{2. $\mathrm{Al}$ 溶湯中における $\mathrm{SiO}_{2}$ 棒の還元反応}

純 $\mathrm{Al}$ 溶湯执よび $\mathrm{Al}-\mathrm{Mg}$ 合金溶湯に $\mathrm{SiO}_{2}$ 棒を浸漬し，引 上げた後に撮影した漫漬部断面のマクロ写真をFig. 4 亿示 す.すべての試料で，反応生成層には多くの亀裂が認められ る。また，超音波加振によって反応層厚さが増し，純 $\mathrm{Al}$ 溶 湯中では約 $0.4 \mathrm{~mm}$ から約 $0.6 \mathrm{~mm}$ へ, $\mathrm{Al}-\mathrm{Mg}$ 合金溶湯の場 合飞は, 約 $0.9 \mathrm{~mm}$ から約 $1.2 \mathrm{~mm}$ 飞増加する。これは超音 波加振に上り, $\mathrm{SiO}_{2}$ と溶湯との濡九性が改善され，速やか に反応が開始することに加光て，反応層に隣接して生じる

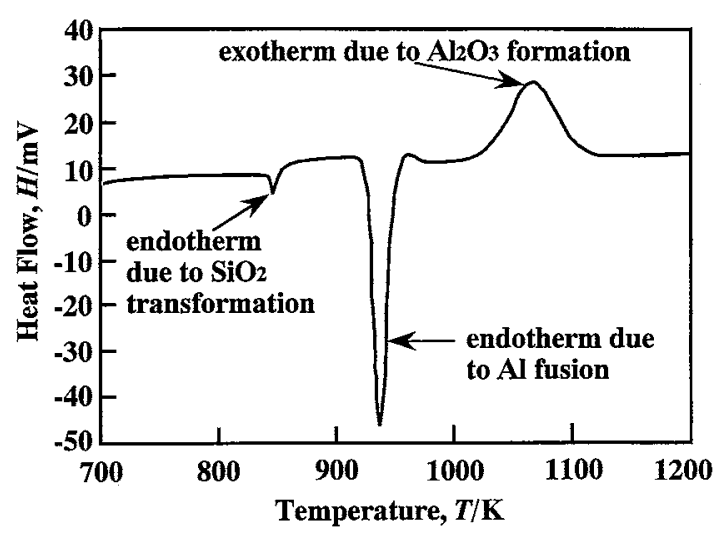

Fig. 3 Resultant curve obtained from DTA scan on premixed $\mathrm{SiO}_{2}$ particles and $\mathrm{Al}$ powder (molar ratio of $\mathrm{SiO}_{2} / \mathrm{Al}=0.75$ ) heated with $0.17 \mathrm{~K} / \mathrm{s}$ in Ar atmosphere.
$\mathrm{Si}, \mathrm{Mg}$ の搪散層が薄くなるためと考克られる。また, 後述 の上5 $\mathrm{K}, \mathrm{SiO}_{2}$ 上りる $\mathrm{Al}_{2} \mathrm{O}_{3}$ 等の安定酸化物の密度が高い ことから, 反応化伴う收縮比って間腺や亀裂が発生し, 溶 湯から反応界面への $\mathrm{Al}$ と $\mathrm{Mg}$ の供給括上び溶湯側への $\mathrm{Si}$ の排出が容易沈なることも影響する。一方，純 $\mathrm{Al}$ 溶湯より も $\mathrm{Al}-\mathrm{Mg}$ 合金溶湯の方が反応層が厚くなる。これは $\mathrm{Mg} の$ 合金化により溶湯と $\mathrm{SiO}_{2}$ との需れ性が改善されるためと考 えられる。

純 $\mathrm{Al}$ 溶湯に $\mathrm{SiO}_{2}$ 棒を浸漬した際の反応層断面に打沙る 元素分布を調べるため，試料断面のEMPAによるライン分 析を行い，その代表的な結果をFig. 5 以示す.超音波加振 の有無沟わらず, 未反応 $\mathrm{SiO}_{2}$ の外側の反応層には $\mathrm{Al}$ と ○が認められ，Si の存在は僅かである。

$\mathrm{Al}-\mathrm{Mg}$ 合金溶湯への浸漬炕よって生じた反應層断面のラ イン分析結果をFig. 6 亿示す。反応層の最表面には $\mathrm{Mg}$ と $\mathrm{O}$ が存在し，A1 は認められない点が特徴的である。また，
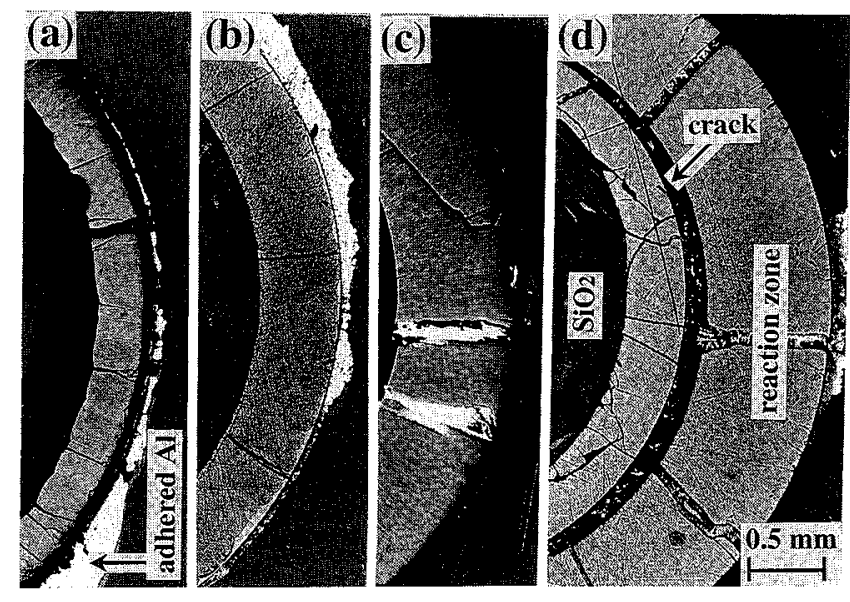

Fig. 4 Optical micrographs showing the reaction zone of $\mathrm{SiO}_{2}$ bar immersed at $1073 \mathrm{~K}$ for $1.8 \mathrm{ks}$, (a) in molten $\mathrm{Al}$ without ultrasound, (b) in molten Al with ultrasound, (c) in molten $\mathrm{Al}-\mathrm{Mg}$ alloy without ultrasound, (d) in molten $\mathrm{Al}-\mathrm{Mg}$ alloy with ultrasound.

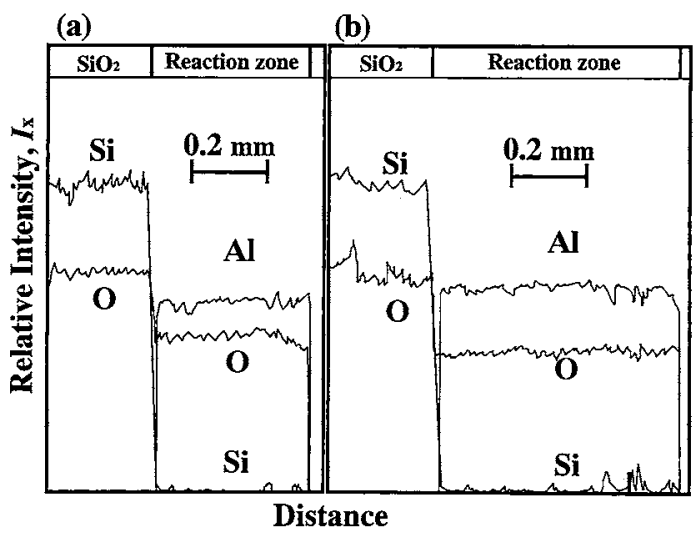

Fig. 5 Intensity profiles of characteristic X-ray in crosssectional reaction zone of $\mathrm{SiO}_{2}$ bar immersed in molten $\mathrm{Al}$ at $1073 \mathrm{~K}$ for $1.8 \mathrm{ks}$, (a) without ultrasound and (b) with ultrasound. 
反応層はほ济 $\mathrm{Mg}, \mathrm{A} 1$ 打よび Oで構成されており，Si 量は 極めて少ない，反応層内の亀裂部に $\mathrm{Al}$ が存在するものと， 存在しないものが認められる.A1が存在する龟裂の発生は, 主として溶湯中で $\mathrm{SiO}_{2}$ が密度の高い安定酸化物に変化する 際の収縮により生じる，その龟裂に溶湯が浸入したと理解さ れる. Alが存在しない亀裂は，安定酸化物の生成之は無関 係な凝固中に生じたるのと考兄られる。

以上のライン分析と X 線回折結果から予測される反応層 の模式図を Fig. 7 飞示す。純 $\mathrm{Al}$ 溶湯への浸漬の場合，溶湯 から供給される $\mathrm{Al}$ は, $\mathrm{SiO}_{2}$ 棒表面の $\mathrm{O}$ と反応して $\mathrm{Al}_{2} \mathrm{O}_{3}$ を生成する。還元された Si は溶湯中に排出される。その後,

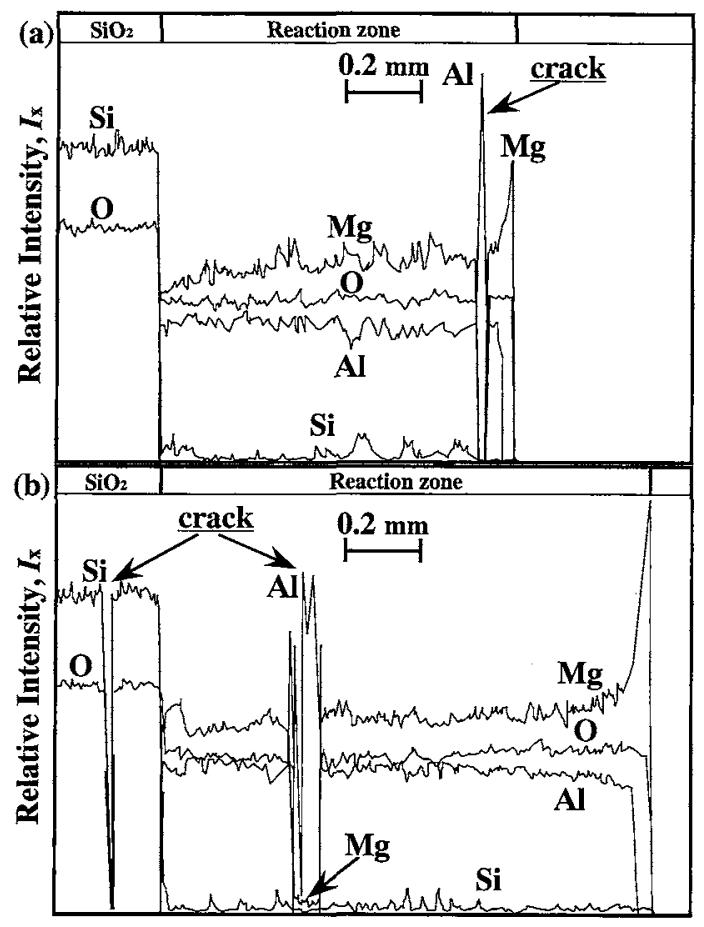

Distance

Fig. 6 Intensity profiles of characteristic X-ray in crosssectional reaction zone of $\mathrm{SiO}_{2}$ bar immersed in molten $\mathrm{Al}-\mathrm{Mg}$ alloy at $1073 \mathrm{~K}$ for $1.8 \mathrm{ks}$, (a) without ultrasound and (b) with ultrasound.

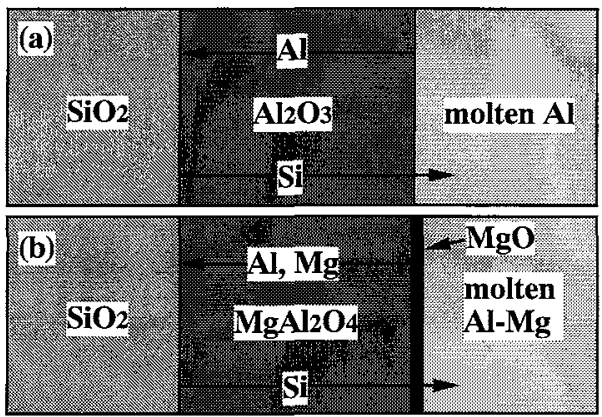

Fig. 7 Schematic drawing of reaction zone of $\mathrm{SiO}_{2}$ bar immersed in (a) molten $\mathrm{Al}$ and (b) molten $\mathrm{Al}-\mathrm{Mg}$ alloy.
$\mathrm{Al}_{2} \mathrm{O}_{3}$ 反応層を通して $\mathrm{SiO}_{2}$ と反応層界面への $\mathrm{Al}$ の供給と溶 湯中への $\mathrm{Si}$ の排出現象を伴いながら，反応界面は $\mathrm{SiO}_{2}$ 棒の 内部へと進行する。一方， Al-Mg 合金溶湯への浸漬では， $\mathrm{SiO}_{2}$ 棒の表面に $\mathrm{MgO}$ が生成し，この $\mathrm{MgO}$ 層の内側ではス ピネル型の $\mathrm{MgAl}_{2} \mathrm{O}_{4}$ が生成する.この理由として, $\mathrm{SiO}_{2}$ と $\mathrm{Mg}$ 濃度の異なる $\mathrm{Al}$ 溶湯との反応化ついて考光ると，溶湯 と接している部分は $\mathrm{Mg}$ の活量が高く，Mg 濃度が約 1.5 mass\%以上の場合, $\mathrm{MgAl}_{2} \mathrm{O}_{4}$ よりる $\mathrm{MgO}$ の生成が優先す るため(20) と考克られる。

\section{3. 生成複合化プロセスへの超音波振動の適用}

（1）テルミット反応による溶湯温度の上昇

$\mathrm{Al}-\mathrm{Mg}$ 合金溶湯表面に $\mathrm{SiO}_{2}$ 粒子を添加し，溶湯擋拌のみ と超音波加振した擋汼を行った時，溶湯温度の時間変化を Fig. 8 亿示与。ただし，擋汼の開始と同時に外部加熱は中 止した. $\mathrm{SiO}_{2}$ 粒子を添加しないものは溶湯温度が単調に低 下寸る，超音波振動を加えた方が，擋汼だけよりも温度低下 が若干速くなる. $\mathrm{SiO}_{2}$ 粒子を添加したものは, 超音波加振 の有無以拘わらず，テルミット反応は進行し，溶湯温度が上 昇する。しかしながら，溶湯擋拌のみでは，溶湯の温度上昇

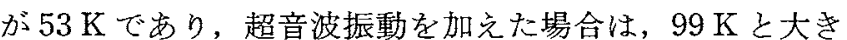
い溶湯温度の上昇が認められる。これは超音波振動によっ て, 多くの $\mathrm{SiO}_{2}$ 粒子が速やかに溶湯中に移行し，テルミッ 卜反応が促進されるためと理解される。しかし，90sを過 ぎると，急激に溶湯温度が低下する，添加した全 $\mathrm{SiO}_{2}$ 粒子 が瞬時汇反応を開始しないことや，反応系外への擋拌に伴う 放熱のため, 計算値よりも溶湯の温度上昇は小さいが, $\mathrm{SiO}_{2}$ 粒子と溶湯間の濡孔性を改善し，安定酸化物の生成反応を促 進する効果は十分に期待できる。

(2) $\mathrm{Al}_{2} \mathrm{O}_{3}$ の生成複合化

純 $\mathrm{Al}$ 溶湯表面に $\mathrm{SiO}_{2}$ 粒子を添加し，超音波加振しなが ら $3.6 \mathrm{ks}$ 間擋捧した。 反応生成した $\mathrm{Al}_{2} \mathrm{O}_{3}$ 粒子を含导複合

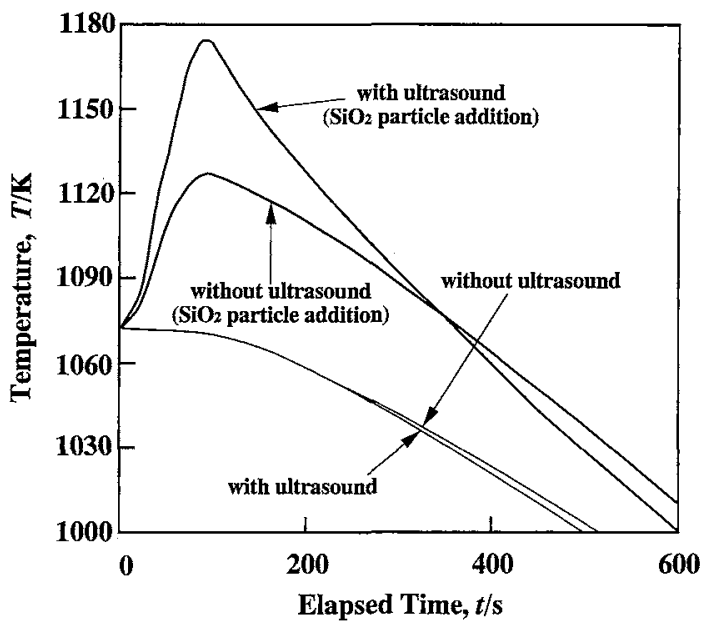

Fig. 8 Change in temperature of molten Al-3 mass $\% \mathrm{Mg}$ alloy as a function of elapsed time after $\mathrm{SiO}_{2}$ particle addition at 1073 $\mathrm{K}$. 
スラリーを冷却した後, 光学顕徽鏡で観察した断面写真を Fig. 9 に示す. $7.4 \mathrm{vol} \%$ の $\mathrm{SiO}_{2}$ 粒子が溶湯に取込まれ，そ のすべてが $\mathrm{Al}_{2} \mathrm{O}_{3}$ になっている. $\mathrm{SiO}_{2}$ 粒子から排出された Si は, マトyックス中に移行する。同一条件で超音波加振 しない場合， $\mathrm{SiO}_{2}$ 粒子は溶湯に全く取込まれず，超音波振 動の效果が証明されている。すなわり，超音波振動により， $\mathrm{SiO}_{2}$ 粒子と $\mathrm{Al}$ 溶湯との見掛けの濡れ性が改善され，粒子は 溶湯中に移行し易くなる。テルミット反応火上り溶湯温度が 上昇するので，需れ性はさらに改善される。その結果，多く の $\mathrm{SiO}_{2}$ 粒子が溶湯中に移行し, $\mathrm{Al}$ 溶湯との反応によって速 やか $\mathrm{K} \mathrm{Al}_{2} \mathrm{O}_{3}$ 粒子となる。

\section{(3) $\mathrm{MgAl}_{2} \mathrm{O}_{4}$ の生成複合化}

$\mathrm{Al}-\mathrm{Mg}$ 合金溶湯表面に $\mathrm{SiO}_{2}$ 粒子を添加し，溶湯擋拌に上 る生成複合化実験を行った．Mgの合金化によって濡れ性が

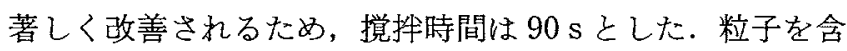
む試料断面を EMPAによってライン分析した結果を Fig. 10 に示す．溶湯擋拌だけの場合，生成した酸化物粒子を構

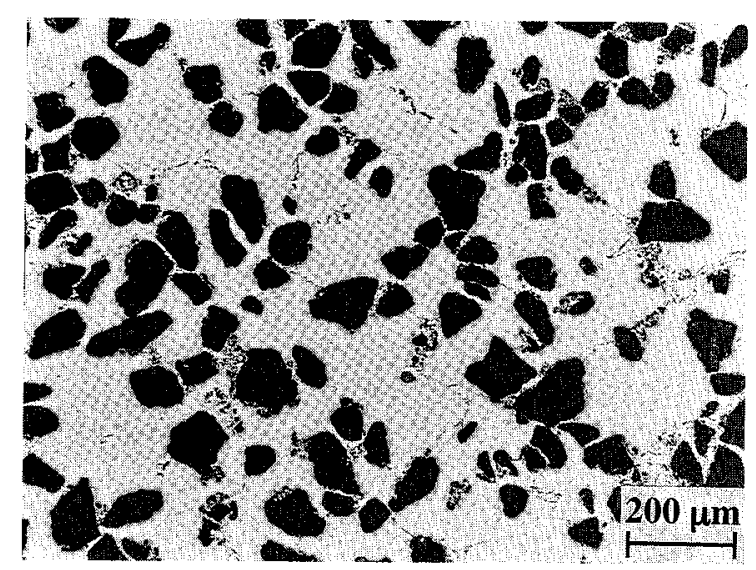

Fig. 9 Optical micrograph showing engulfed particles by melt stirring with ultrasonic vibration at $1073 \mathrm{~K}$ for $3.6 \mathrm{ks}$. note: transferred $\mathrm{SiO}_{2}$ particles are changed into $\mathrm{Al}_{2} \mathrm{O}_{3}$ due to the reaction with molten pure $\mathrm{Al}$.

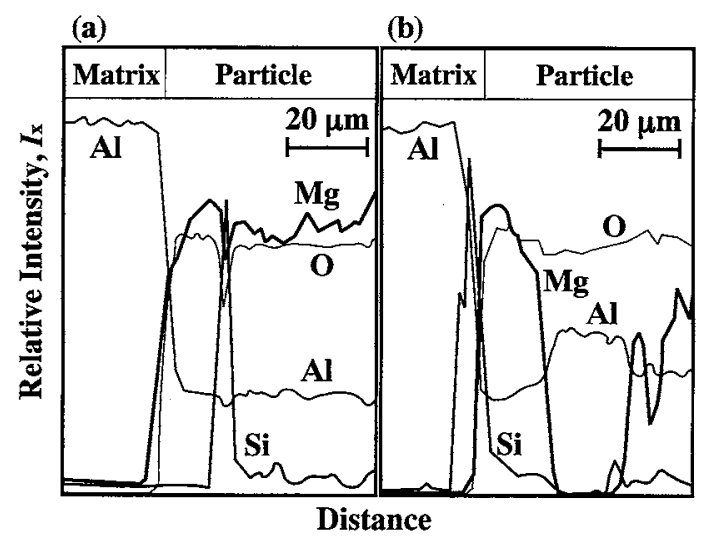

Fig. 10 Intensity profiles of characteristic X-ray in crosssection of engulfed particle by melt stirring at $1073 \mathrm{~K}$ for $90 \mathrm{~s}$, (a) without ultrasound and (b) with ultrasound.
成する $\mathrm{Mg}, \mathrm{A} 1, \mathrm{O}$ の濃度比が一定であり，酸化物は一種類 と考光られる。超音波加振した溶湯擋䢁では，酸化物粒子内 に $\mathrm{Mg}$ と $\mathrm{Al}$ の濃度変動があり，二種類以上の酸化物から構 成されていると予想される。マトリックス中の $\mathrm{Mg}$ 濃度は 低く，その汪とえどが生成した酸化物粒子内に存在してい る。また， $\mathrm{SiO}_{2}$ 粒子から変化した酸化物粒子の亀裂部，抹 よび酸化物粒子とマトリックスの界面に Si の濃化が認めら れる。

Fig. 10 の試料断面に枋けるX 線回折图形 $(\mathrm{CoK} \alpha)$ を Fig. 11 に示す。溶湯擋挥のみに比べて超音波加振した試料では, 生成する $\mathrm{MgAl}_{2} \mathrm{O}_{4}$ 特よび $\mathrm{SiO}_{2}$ から還元される $\mathrm{Si}$ が多く, 末反応の $\mathrm{SiO}_{2}$ が減少している。擋汼時間が短いので $\mathrm{SiO}_{2}$ 粒子の還元は完全に終わっていない，また，溶湯擋挥のみの 時には認められなかった $\mathrm{Al}_{2} \mathrm{O}_{3}$ が生成しており， $\mathrm{Mg}_{2} \mathrm{Si}$ は 認められない.Fig. 6 に認められた $\mathrm{MgO}$ の存在も考えられ るが，X 線回折図形には表れていない。

上記試料断面の光学影销鏡写真を Fig. 12 亿示す. Mgの 合金化によって $\mathrm{SiO}_{2}$ 粒子と溶湯間の濡れ性が改善されるた め, $90 \mathrm{~s}$ と短時間の溶湯擋䢁のみでも 8.2 vol\%の $\mathrm{SiO}_{2}$ 粒子 が溶湯に取込をれ，溶湯中で $\mathrm{MgAl}_{2} \mathrm{O}_{4}$ を生成する。超音波 振動を加えると，濡れ性がさらに改善され，溶湯に取込まれ 可 $\mathrm{SiO}_{2}$ 粒子は $16.4 \mathrm{vol} \%$ をで上昇する。また，超音波加振 した試料には，溶湯に取込をれる $\mathrm{SiO}_{2}$ 粒子が多いにも拘わ

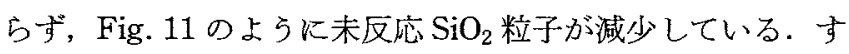
なわち，超音波振動により溶湯中での $\mathrm{MgAl}_{2} \mathrm{O}_{4}$ の反応生成 が促進されている。

$\mathrm{Al}-3$ mass $\% \mathrm{Mg}$ 合金溶湯と 14.6 vol\%の $\mathrm{SiO}_{2}$ 粒子が

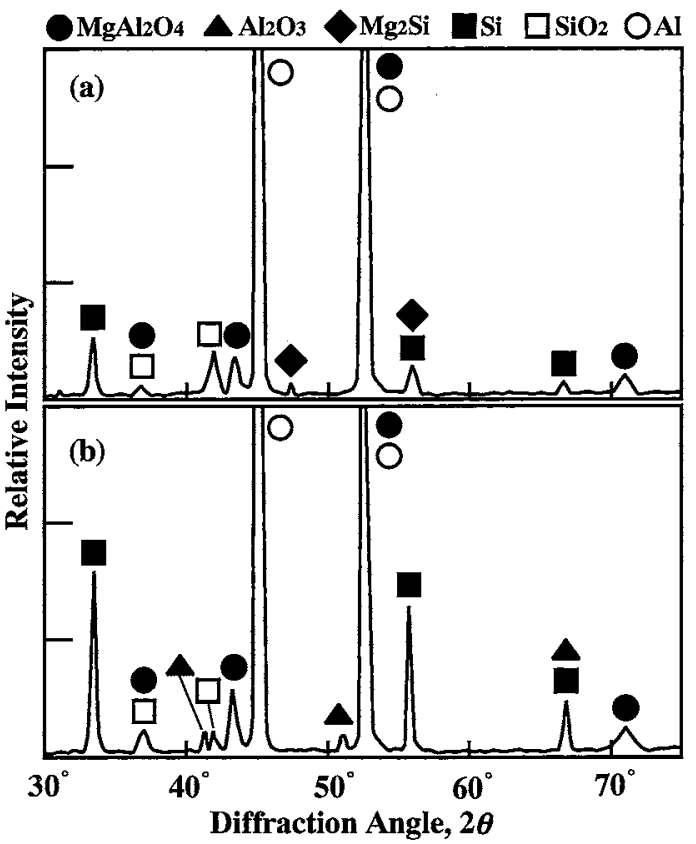

Fig. 11 X-ray diffraction patterns of in-situ composites stirred at $1073 \mathrm{~K}$ for $90 \mathrm{~s}$, (a) without ultrasonic vibration, (b) with ultrasonic vibration. 


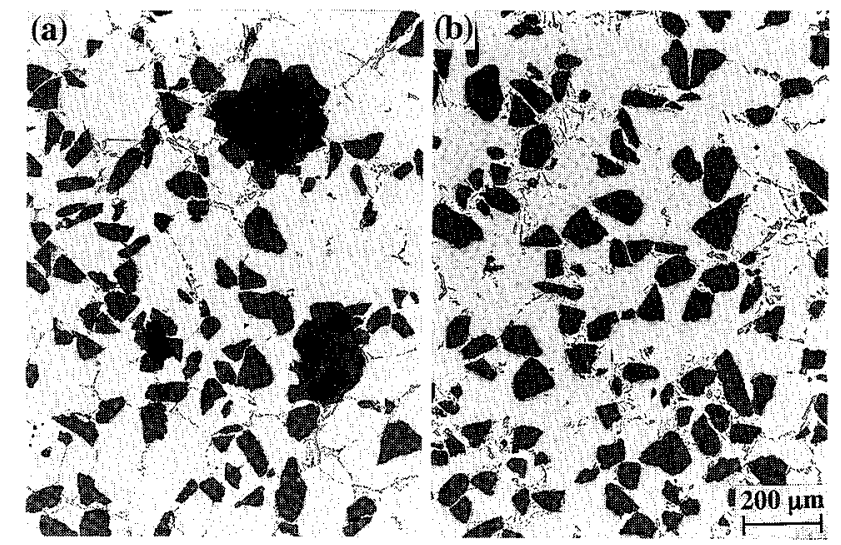

Fig. 12 Optical micrographs showing engulfed particles by melt stirring at $1073 \mathrm{~K}$ for $90 \mathrm{~s}$, (a) without ultrasonic vibration, (b) with ultrasonic vibration.

note: transferred $\mathrm{SiO}_{2}$ particles are mainly changed into $\mathrm{MgAl}_{2} \mathrm{O}_{4}$ due to the reaction with molten Al-Mg alloy.

$\mathrm{MgAl}_{2} \mathrm{O}_{4}$ を生成すれば, 溶湯中の $\mathrm{Mg}$ が完全に消費される. したがって，14.6 vol\%以上の $\mathrm{SiO}_{2}$ 粒子が溶湯中に䔟行す る場合には， $\mathrm{MgAl}_{2} \mathrm{O}_{4}$ に加克て $\mathrm{Al}_{2} \mathrm{O}_{3}$ が生成する。溶湯擋 拌のみでは，溶湯炕取込をれる $\mathrm{SiO}_{2}$ 粒子は $8.2 \mathrm{vol} \%$ であ ので，そのすべてが $\mathrm{MgAl}_{2} \mathrm{O}_{4}$ 孛生成する。マトリックス溶 湯に排出された Si の一部は，溶湯中に残っている $\mathrm{Mg}$ と反 応し，凝固時に化合物相 $\mathrm{Mg}_{2} \mathrm{Si}$ を生成する。超音波加振し た溶湯擋挥の場合，溶湯に移行した $16.4 \mathrm{vol} \%$ の $\mathrm{SiO}_{2}$ 粒子 中, $14.6 \mathrm{vol} \%$ が $\mathrm{MgAl}_{2} \mathrm{O}_{4}$ を生成し, 残る $1.8 \mathrm{vol} \%$ の $\mathrm{SiO}_{2}$ 粒子は $\mathrm{Al}_{2} \mathrm{O}_{3}$ 在生成する。溶湯に排出された Si は， $\mathrm{Mg}$ が

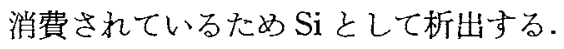

溶湯擋挥だけの場合は，溶湯に取込をれた粒子と $\mathrm{Al}$ 合金 溶湯とは完全には濡れて和らず，Fig. 12(a)のように，雾囲 気の $\mathrm{Ar}$ を巻込んだ欠陥が粒子凝集部に多数認められる.画 像解析に上りこのガス欠宿の平均体積率を測定すると 5.7 vol\%Kなる。しかし，超音波加振を行うと，粒子の全周が $\mathrm{A} 1$ 合金マトリックスに囲委れて拈り，准は認められなく なる、したがって，超音波振動を加光ると，安定酸化物生成 量の增加だけではなく，ガス欠陷の発生を防ぎ，粒子の複合 化状態を改善する効果がある。

（4）安定酸化物の生成に伴う収縮による空隙の発生

溶湯表面に $\mathrm{SiO}_{2}$ 粒子を添加し，超音波加振しながら 3.6 $\mathrm{ks}$ 間の溶湯撹汼を行った試料中に生成する酸化物粒子断 面の SEM 写真を Fig. 13 亿示寸。（a） $\mathrm{Al}$ 溶湯中で生成し た $\mathrm{Al}_{2} \mathrm{O}_{3}$ であり，(b)は $\mathrm{Al}-\mathrm{Mg}$ 合金溶湯中で生成した $\mathrm{MgAl}_{2} \mathrm{O}_{4}$ である. $3 \% \mathrm{NaOH}$ 水溶液を用いた深腐食により， 粒子内部の金属マトリックスは除去され，多くの微細間隙が 認められる。この間陌の発生は， $\mathrm{SiO}_{2}$ から $\mathrm{Al}_{2} \mathrm{O}_{3}$ あるいは $\mathrm{MgAl}_{2} \mathrm{O}_{4}$ を生成する際の密度の差による収縮に起因すると 考它られる. $\mathrm{SiO}_{2}$ から $\mathrm{Al}_{2} \mathrm{O}_{3}$ または $\mathrm{MgAl}_{2} \mathrm{O}_{4}$ を生成する際 の密度の差による収縮は，それぞれ $34.8 \%, 23.9 \%$ と計算さ れる。したがって， $\mathrm{Al}_{2} \mathrm{O}_{3}$ の方が $\mathrm{MgAl}_{2} \mathrm{O}_{4}$ よりを収縮が大
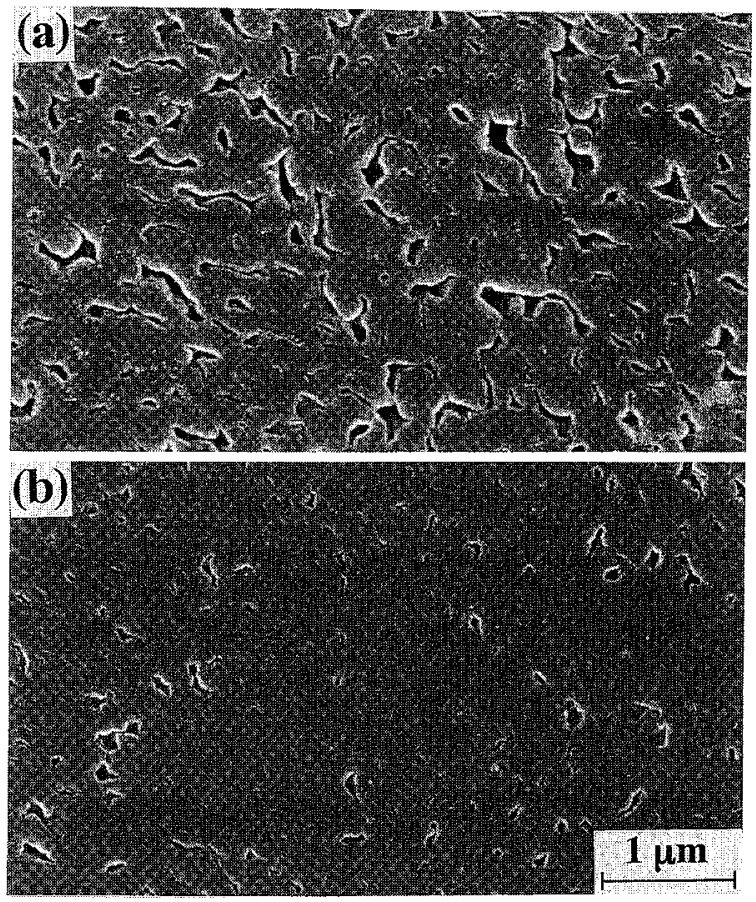

Fig. 13 Scanning electron micrographs showing a crosssectional microstructure of oxide by melt stirring with ultrasonic vibration at $1073 \mathrm{~K}$ for $3.6 \mathrm{ks}$.

note: (a) transferred $\mathrm{SiO}_{2}$ particles are changed into $\mathrm{Al}_{2} \mathrm{O}_{3}$ due to the reaction with molten pure Al.

(b) transferred $\mathrm{SiO}_{2}$ particles are mainly changed into $\mathrm{MgAl}_{2} \mathrm{O}_{4}$ due to the reaction with molten Al-Mg alloy.

きく,Fig.13(a)のよ5に多数の锁細間隙が認められる。間 腺老通じて $\mathrm{Al} や \mathrm{Mg}$ の供給が容易になり， $\mathrm{Al}_{2} \mathrm{O}_{3} や$ $\mathrm{MgAl}_{2} \mathrm{O}_{4}$ の生成複合化が進行する。

（5）生成酸化物粒子の微細化

$3.6 \mathrm{ks}$ 間の溶湯擋拌によって生成した $\mathrm{MgAl}_{2} \mathrm{O}_{4}$ 粒子の $d_{\mathrm{e}}$ を，画像解析により測定した。その $d_{\mathrm{e}}$ のとスドラムを Fig. 14 亿示す。供試 $\mathrm{SiO}_{2}$ 粒子の平均 $d_{\mathrm{e}}$ は $86 \mu \mathrm{m}$ ですり， 超音波加振を併用しない溶湯擋汼の場合，生成した $\mathrm{MgAl}_{2} \mathrm{O}_{4}$ 粒子の平均 $d_{\mathrm{e}}$ は $83 \mu \mathrm{m}$ とほぼ同等である。しか しながら，超音波加振によって $50 \mu \mathrm{m}$ 以下の粒子が増え， 平均 $d_{\mathrm{e}}$ \& $75 \mu \mathrm{m}$ に減少している.

超音波加振した Fig. 14 (b) 試料中の $\mathrm{MgAl}_{2} \mathrm{O}_{4}$ 粒子の拡大 写真を Fig. 15 に示す. $\mathrm{MgAl}_{2} \mathrm{O}_{4}$ 粒子には刍裂が生じてい る. 寸なわち，超音波振動により生成酸化物粒子の微細化が 促進され，その寸法が小さくなる。したがって，溶湯に取込 まれ易い大きな $\mathrm{SiO}_{2}$ 粒子を添加してる，超音波振動により 生成酸化物粒子が微細化され，MMC の機械的性質を向上で さる可能性がある。

\section{N. 結 言}

$\mathrm{O}$ 供給源として添加した $\mathrm{SiO}_{2}$ 粒子を, 純 $\mathrm{Al}$ 溶晹亦るい は Al-Mg 合金溶湯中へ移行させ， $\mathrm{Al}_{2} \mathrm{O}_{3}$ や $\mathrm{MgAl}_{2} \mathrm{O}_{4}$ など安 


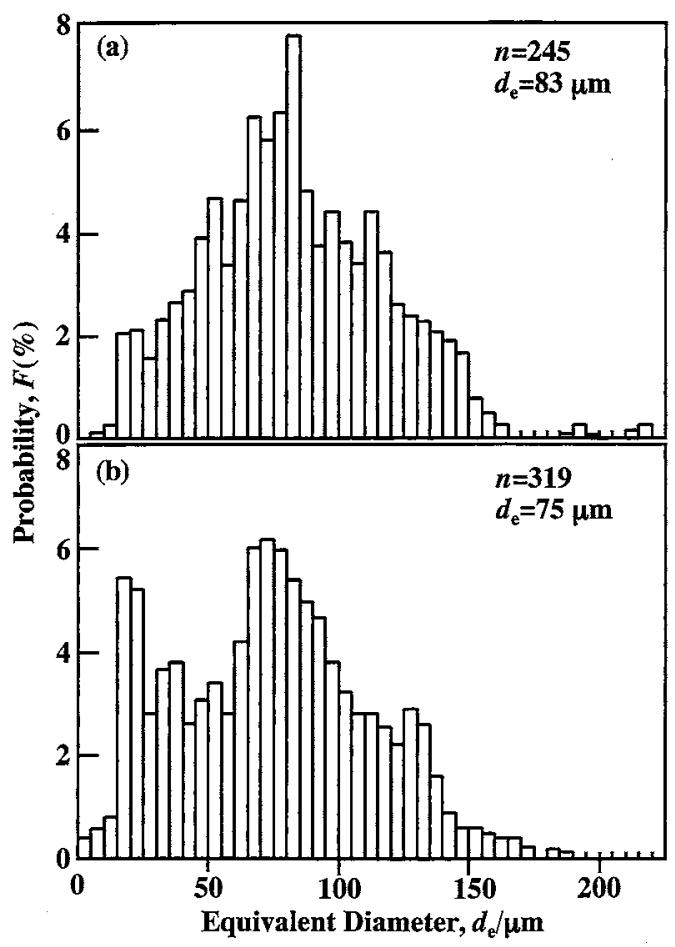

Fig. 14 Histograms of equivalent particle diameter engulfed by melt stirring at $1073 \mathrm{~K}$ for $3.6 \mathrm{ks}$, (a) without ultrasonic vibration (b) with ultrasonic vibration.

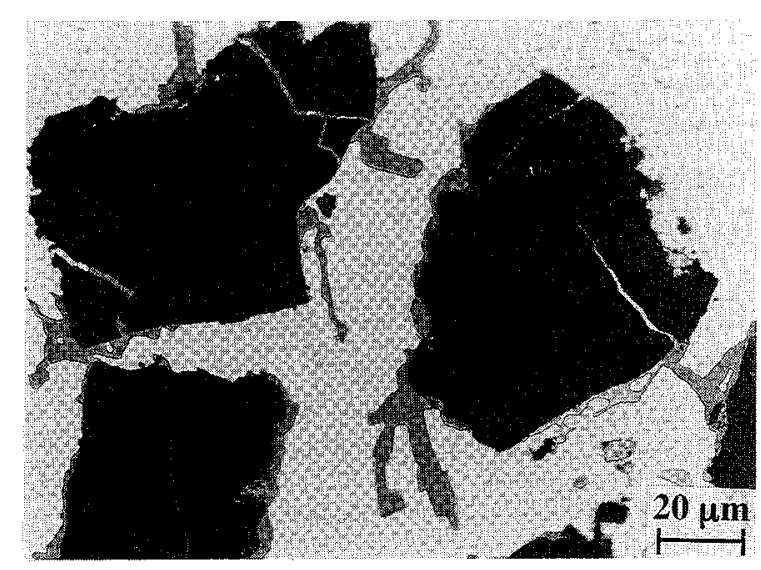

Fig. 15 Optical micrograph showing cracks in $\mathrm{MgAl}_{2} \mathrm{O}_{4}$ particles formed by melt stirning with ultrasonic vibration at 1073 $\mathrm{K}$ for $3.6 \mathrm{ks}$.

定酸化物を生成させる生成複合化プロセスに超音波振動を適 用し，以下の結論を得た。

（1）純 $\mathrm{Al}$ 溶湯中に浸漬した $\mathrm{SiO}_{2}$ 棒の反応層は $\mathrm{Al}_{2} \mathrm{O}_{3}$ で 方り， $\mathrm{Al}-\mathrm{Mg}$ 合金溶湯中では表面層に $\mathrm{MgO}$ ，反応層内部沱 $\mathrm{MgAl}_{2} \mathrm{O}_{4}$ を生成する。超音波振動を加えると, $\mathrm{Al}_{2} \mathrm{O}_{3}$ と $\mathrm{MgAl}_{2} \mathrm{O}_{4}$ の生成が促進される。

(2) 純 $\mathrm{Al}$ 溶湯あるいは $\mathrm{Al}-\mathrm{Mg}$ 合金溶湯と $\mathrm{SiO}_{2}$ 粒子が反
応すると，発熱によって溶湯温度が上昇する. $\mathrm{Al}-\mathrm{Mg}$ 合金 溶湯の場合，超音波加振すると溶湯の温度が $99 \mathrm{~K}$ 上昇する.

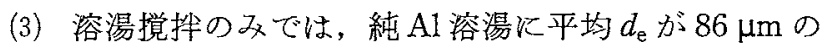
$\mathrm{SiO}_{2}$ 粒子は全く取込まれない，超音波加振すると， $\mathrm{SiO}_{2}$ 粒 子は $\mathrm{Al}$ 溶湯中に取込まれ，安定酸化物 $\mathrm{Al}_{2} \mathrm{O}_{3}$ を生成する。

(4) $\mathrm{Al}-\mathrm{Mg}$ 合金溶湯中に取込をれる $\mathrm{SiO}_{2}$ 粒子は，主に $\mathrm{MgAl}_{2} \mathrm{O}_{4}$ と $\mathrm{Al}_{2} \mathrm{O}_{3}$ を生成する。超音波加振による湍孔性改

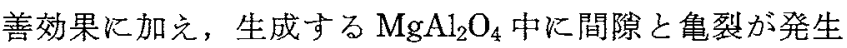
し， $\mathrm{SiO}_{2}$ の反応界面への $\mathrm{A} 1$ とg の供給および $\mathrm{Si}$ の排出 が增すため，生成複合化が促進される，亀裂の導入により， 添加 $\mathrm{SiO}_{2}$ 粒子より铛細な生成酸化物粒子を含む $\mathrm{MMC}$ 試料 になる。

（5）超音波加振しながら作製した MMC 試料にはガス欠 陷が発生せず，生成した安定酸化物の分散性もよく，超音波 振動は複合化状態の改善にも効果的でする。

本研究は, 文部省科学研究費(08555180)によって行われ たものでありここに特記して深く感謝の意を表します。

\section{文献}

(1) Y. Kajikawa, T. Nukami and M. C. Flemings: Metall. Mater. Trans., 26A(1995), 2155.

（2）金田裕光，長 隆郎：軽金属，45(1995)，321.

(3) M. K. Aghajanian, J. T. Burke, D. R. White and A. S. Nagelberg: 34th Int. SAMPE, SAMPE Press, California, (1989), 817

(4) K. Miwa and T. Ohashi: Proc. of Fifth Japan-U.S. Conf. Comp. Mater., Technomic Pub. Co. Press, Lancaster, (1990), 355.

(5) F. A. Girot, L. Albingre, J. M. Quenisset and R. Naslain: J. Metals, (1987), 18.

(6) K. Miwa, T. Ikeda and T. Ohashi: Proc. of Second Int. Conf. Proc. of Semi-Solid Alloys and Composites, M.I.T. Press, Cambridge, Massachusetts, (1992), 398.

(7) M. S. Newkirk, A. W. Urquhart, H. R. Zwicker and E. Breval: J. Mater. Res., 1(1986), 81.

(8) H. Venugopalan, K. Tankala and T. Debroy: Metall. Mater. Trans., 27B (1996), 43.

(9) T. Nukami and M. C. Flemings: Metall. Mater. Trans., 26A(1995), 1877.

(10) W. Liu and U. Köster: Mater. Sci. Eng., A210(1996), 1.

(11) P. Sahoo and M. J. Koczak: Mater. Sci. Eng., A144(1991), 37.

(12) 森本啓之, 野村正裕, 芦田喜郎：日本金属学会誌，59(1995), 429.

(13) Y. Chen, D. D. L. Chung: J. Mater. Sci., 31 (1996), 311.

(14) H. Nakanishi, Y. Tsunekawa, M. Okumiya and N. Mohri: Mater. Trans., JIM, 34(1993), 62.

(15) Y. Tsunekawa, H. Nakanishi, M. Okumiya and N. Mohri: Trans. AFS, 102 (1994), 953.

（16）弦間喜和，亘川好樹，奥宮正洋，棚田優子，毛利尚武：鋳造 工学, 68(1996), 969 .

(17) Y. Genma, Y. Tsunekawa, M. Okumiya and N. Mohri: Mater. Trans., JIM, 38(1997), 232.

(18) I. Barin: Thermochemical Data of Pure Substances, VCH Pub., Weinheim, (1989), 43.

(19) M. W. Chase, C. A. Davies, J. R. Downey, D. J. Frurip, R. A. McDonald and A. N. Syverud: JANAF Thermochemical Tables, 3rd ed., American Chemical Society and American Institute of Physics Pub., 14(1985), 61.

(20) A. D. Mcleod and C. M. Gabryel: Metall. Trans., 23A (1992), 1279. 